\title{
Facing democratic indeterminacy: the consequences of the Dayton Agreement
}

\begin{abstract}
This article was written to inform the author's presentation to the SEER Journal online workshop on the Dayton Agreement held on 2 July 2021. Focusing on the issues of de-consolidation and de-democratisation which are inhibiting Bosnia and Herzegovina (among other western Balkan states) from becoming a credible EU accession candidate, the article locates the question of 'othering' within the need to rethink international relations given the global issues which are shaping today's world. Drawing on recently published work in the areas of philosophy and international relations, the author identifies three approaches in the failures of cotransformation and transition, concluding that new democratic vistas may be opened for $\mathrm{BiH}$ up by the pursuit of interregional programmes as well as, in response to the climate emergency and its impact on flooding and other natural disasters, within a revitalised bioregional paradigm. None of the maps which arise out of the risks of natural disasters bear any resemblance to the 'logic' of the map drawn at Dayton and, in peacetime, may represent a viable way forward although time is required.
\end{abstract}

Keywords: Dayton Agreement, Bosnia and Herzegovina, transition, territorial cooperation, bioregional paradigm, democratisation

Introduction

To state the obvious, we live in a different world. And, in Francis Bacon's words, 'it is pointless to expect any great advances in science from grafting new things onto old.' Our 'software' dramatically needs to be updated. I still wonder how this happens automatically in the field of AI-driven objects and how difficult it is to achieve the same in the field of international relations, for example.

But, indeed, 'what is to be done'? The question demands a more vigorous and updated thinking: in Jean-Luc Nancy's contemporary phrasing, a truly new critical perspective must precede effective action. This includes the need to question established significances, institutions and representations: reframing and rethinking are pre-conditions for the emergence of new significances and values. Rethinking international relations must, most notably, take into account the global issues which are shaping today's world. In my view, these are: the Anthropocene age in which we live, marked by significant human impact on geology and Earth's ecosystems; degrowth; and the shift from the post-Wall period to an era of transitions. In what follows, I try briefly to discuss these topics, building in the first section on earlier contributions made in the SEER Journal (Solioz 2020a). 
The fate of cotransformation and transitions

Václav Havel coined the notion of the 'uncanny era of Post-Communism' in 1991. Today, while the east-west gap is re-emerging, and the core-periphery gap widening, we may rephrase Havel's idea: while on the one hand the European Union has successfully enlarged and promised integration, convergence and consolidation; on the other the trends of disintegration, de-convergence and de-consolidation have become more apparent and tend currently to have the upper hand over the former.

Three different approaches could be considered here.

The first one is based on the path of differentiated integration and introduces a relevant sequencing of post-Wall Europe. Attila Ágh (2019; see also Solioz 2020b) identifies three phases of systemic change outlining this 'uncanny era': a first decade (the 1990s), characterised by the relative de-democratisation model and consolidation paradigm; a second (the 2000s), marked by partial de-consolidation; and the third (the 2010s), typified by the absolute de-democratisation model alongside deconsolidation.

Within this framing, the second post-Wall decade plays a pivotal role: the quest for sovereignty signalled, instead of a 'Return to Europe', the 'Return of the Nation' and structured both the political scenes and the various cleavages: class conflict; urban/rural conflict; secularism/religious conflict; and the core-periphery divide (Solioz 2020b: 79-86). This trend paved the way to the rise of the - first soft, then hard authoritarianism and populism ${ }^{1}$ which characterised the third post-Wall decade (Solioz 2020b: 121-145).

As a matter of fact, we are facing today in east-central Europe and the Balkans hybrid regimes with authoritarian features of various kinds but with similar patterns, one of them being stagnation (Florian Bieber (2020) successfully introduced here the notion of 'stabilitocracy'). Summing-up the main investigations readily available in the academic literature, the countries of the region are surfing between waves of formal democracy and informal authoritarianism, simultaneously gaming on several levels; and, not least, are falling in between 'democratic breakdown' (i.e. the transition from democracy to a hybrid or authoritarian regime) and 'democratic regression' (i.e. transition through a loss of democratic quality).

The second approach considers de-convergence, de-consolidation and dedemocratisation as the result of 'weakness politics' as opposed to 'power politics'. While the first waves of EU enlargement were driven by the latter, 'weakness politics' tends to dominate more recent ones and, in the process, greater influence has been given to a number of new actors like traditional authorities, informal networks, warlords, religious representatives, leaders or even mafias.

Furthermore, 'weakness politics' has nurtured the so-called 'Balkan malaise'; a resistance to various strategies to 're-engage' in the Balkans which is particularly evident when it comes to Bosnia and Herzegovina. While power competition no longer

1 Attila Ágh mentions that 'in the first stage of soft populism there was a depoliticization and demobilization effect, whereas in the second stage of hard populism there was a repoliticization and remobilization effect through the soft power of the media.' (Ágh 2019: 160). 
works, weakness appears as one of the most efficient principles. As Bertrand Badie acknowledges, 'weakness politics':

Directly [challenges] traditional power politics, redefining the state as well as its functions and the sovereignty which was its main attribute. (Badie 2020: 7)

The third approach takes a broader perspective and, connecting community and immunity, views the various illiberal tendencies on display as symptoms of the 'age of immunology' (Napier 2003). For Napier, the central assumption of immunology that we survive through the recognition and elimination of non-self - has become a defining concept of the modern age... at the costs of diversity, sociality and liberty. Briefly put, societies are becoming increasingly compartmentalised communities that tolerate the 'other', the foreign body, only in small doses.

In the same vein, Roberto Esposito (2020: 76-77) formulates two theses. First:

The immune system, up to a certain moment only related to the medical and legal fields, at a certain point has been extended to all sectors and languages of our life, to the point of becoming the point of coagulation, real and symbolic, of contemporary experience.

And second:

The immunity necessary to protect our life - never as today do we experience how much we need it - if taken beyond a certain limit, ends up denying it. It forces life into a sort of cage where we risk not only losing our freedom, but also the very meaning of our individual and collective existence.

Hence the arrival of an insistent paradox:

What protects the body, both personal and social, can also block its development. It could be said that high-dose immunization means sacrification of qualified life, to the reasons of simple survival.

In my view, a process-oriented approach should connect those concepts that are otherwise thought to be irreconcilable, exclusive or in opposition to each other and should overcome such systematic polarisations. Focusing on this most pressing issue, Esposito had earlier already argued that community and immunity should not be seen as opposite polarities but as two distinct sides of the same entity, both immune and common (Esposito 2011). Of course, at the time of preparation for this workshop, we are witnessing an abnormal surge of requests for immunity; while the balance between communitas and immunitas seems to be broken in favour of the latter.

Esposito sees the solution in the activation of new spaces of collective experiences and that:

The production of common spaces, spheres and dimensions must be placed side by side with the dissolution of the overly restrictive immune bonds. (Esposito 2020: 78) 
This is a view that particularly relates to the fate of Bosnia and Herzegovina, a terrain where the return of community, of the common good, must be thought and enacted.

To return now to one of the issues first mentioned above, instead of opposing democratisation and de-democratisation, we may observe - recapturing here the concept of complementarity and Donna Haraway's idea of 'staying with the trouble' (Haraway 2016) - that both are continuous and interconnected processes related to democracy and not (necessarily) to non-democracy. As Charles Tilly pinpoints:

Democratization is a dynamic process that always remains incomplete and perpetually runs the risk of reversal - of de-democratization. Closely related processes, moving in opposite directions, produce both democratization and de-democratization. (Tilly 2007: xi)

Of course, this dynamic manufactures an ambiguity characterising what different authors conceive of as the 'politics of uncertainty'.

The paradoxes of ongoing multiple transition processes can be further identified as an oscillating phenomenon - a back and forth between the regional level and the national; formality and informality; consolidation and de-consolidation; democratisation and de-democratisation; etc. The 'age of transition' is thus marked by instability, movement, alterations and ruptures. This requires a 'multiplex approach' in order to capture the new trends: polymorphous rather than unidimensional; more 'flux' and less 'form'; and increased autonomy rather than control. A country-based approach, focusing on Bosnia and Herzegovina, provides the opportunity to make the first steps in such a direction.

\section{Bosnia and Herzegovina from grey to green}

The 'uneasiness' in Bosnia and Herzegovina was reloaded in April 2021 by the 'Slovenian non-paper' exploring a 'peaceful' redrawing of the country's borders along ethnic lines: accordingly, Serbia would absorb the existing entity of Republika Srpska, one of the country's two main administrative units, while its ethnic Croat majority cantons would join Croatia. Bosnia and Herzegovina would thus remain cut down to about one-third of its size. Last, but not least, Albania would unify with Albanian-majority areas in Kosovo and in North Macedonia. ${ }^{3}$

The Slovenian prime minister, Janez Janša, who took over the rotating presidency of the Council of the EU on 1 July 2021, denied the existence of the memo. However, the document appears to be authentic and amounts to more than just a bit of kite-flying, the logic behind it being the view that the 'dissolution of Yugoslavia is unfinished'. Such discussions serve to illustrate the omnipotence of three - key, but

2 For a global approach across a range of domains and diverse case studies, see Scoones and Stirling (2020).

3 The non-paper was published on 15 April 2021 by the Slovenian website Necenzurirano. There was some speculation as to whether the non-paper was drafted by, or otherwise relates to, a document written in 2011 by the former Slovenian president, Milan Kučan, who claims, however, that his report is not about changing borders ('Kučanov non-paper' Večer 11 June 2021). The 'Kučan document' has been published by Božo Repe (2015: 560-574). 
outdated - norms of the Westphalian 'software': sovereignty; territoriality; and international negotiations.

We should do away with a Eurocentric perspective, away with the outdated Westphalian model of 1648, away with traditional geopolitics and away with this fossilising approach in favour of a multiplex world order made up of more complex and more fluid political finalities that would move us beyond a state-centred understanding of power and territory to encompass multi-actor, multi-level and multi-scalar processes.

Departing from state-centred approaches would thus permit the incorporation of oft-neglected micro-politics - via a consideration of regional, urban and network levels. This matters particularly in Bosnia and Herzegovina as the country is structured far more by the uneven development between urban and rural regions than by the socalled 'ethnic' conflict (Bougarel 1996).

First, we may mention the cooperation forums and cross-border working communities (see Map 1), as well as European territorial cooperation, better known as Interreg, involving national, regional and local actors which have been engaged since 1990 in three strands of cooperation - cross-border; transnational; and interregional (Stubbs and Solioz 2012; Solioz 2017). ${ }^{4}$ These projects matter in as much as crossborder programmes represent 40 per cent of the territory of the European Union. Note that these EU programmes have been installed in all the former Yugoslav republics (as part of the Instruments for Pre-Accession Assistance) as well as EU nonmember countries to the east and the south (in the framework of the European Neighbourhood Policy).

Second, bioregions also fit into this framework. The concept of a bioregion gains new meaning against the background of the Anthropocene epoch ${ }^{5}$ and due to the necessity to envision an era of degrowth. ${ }^{6}$ Typically, a bioregion is understood as a unique region definable by natural (rather than political) boundaries with a geographic, climatic, hydrological and ecological character capable of supporting unique human and non-human living communities. As Robert Thayer puts it:

Bioregions can be variously defined by the geography of watersheds, similar plant and animal ecosystems, and related, identifiable landforms (e.g., particular mountain ranges, prairies, or coastal zones) and by the unique human cultures that grow from natural limits and potentials of the region. Most importantly, the bioregion is emerging as the most logical locus and scale for a sustainable, regenerative community to take root and to take place. (Thayer 2003: 3)

4 It is notable that one region, for example from Croatia, may be involved in various strands; and, additionally, in the framework of one strand, for example on interregional cooperation, within various programmes (central Europe, Adriatic-Ionian and the Danube Area).

5 For a powerful critical appraisal of the Anthropocene, see Frédéric Neyrat (2018).

6 The founding fathers of bioregionalism, Peter Berg and Raymond Dasmann, published in 1977 'Reinhabiting California', a key text which was recently republished in the volume edited by Cheryll Glotfelty and Eve Quesnel (2015), pp. 35-40. 
Notably Peter Berg, the pioneering environmental writer and activist - founder of the Diggers in the 1960s and, later on, of the Planet Drum Foundation - coined, as a clearer alternative to 'bioregion', the term 'life-place' (Berg 1995). To sum up, bioregionalism is a democratically defined and environmentally decentralised approach involving grassroots networks based on an alternative paradigm (see Table 1).

\section{Map 1 - Regional cross-border co-operation in the Balkans (2014-2020)}

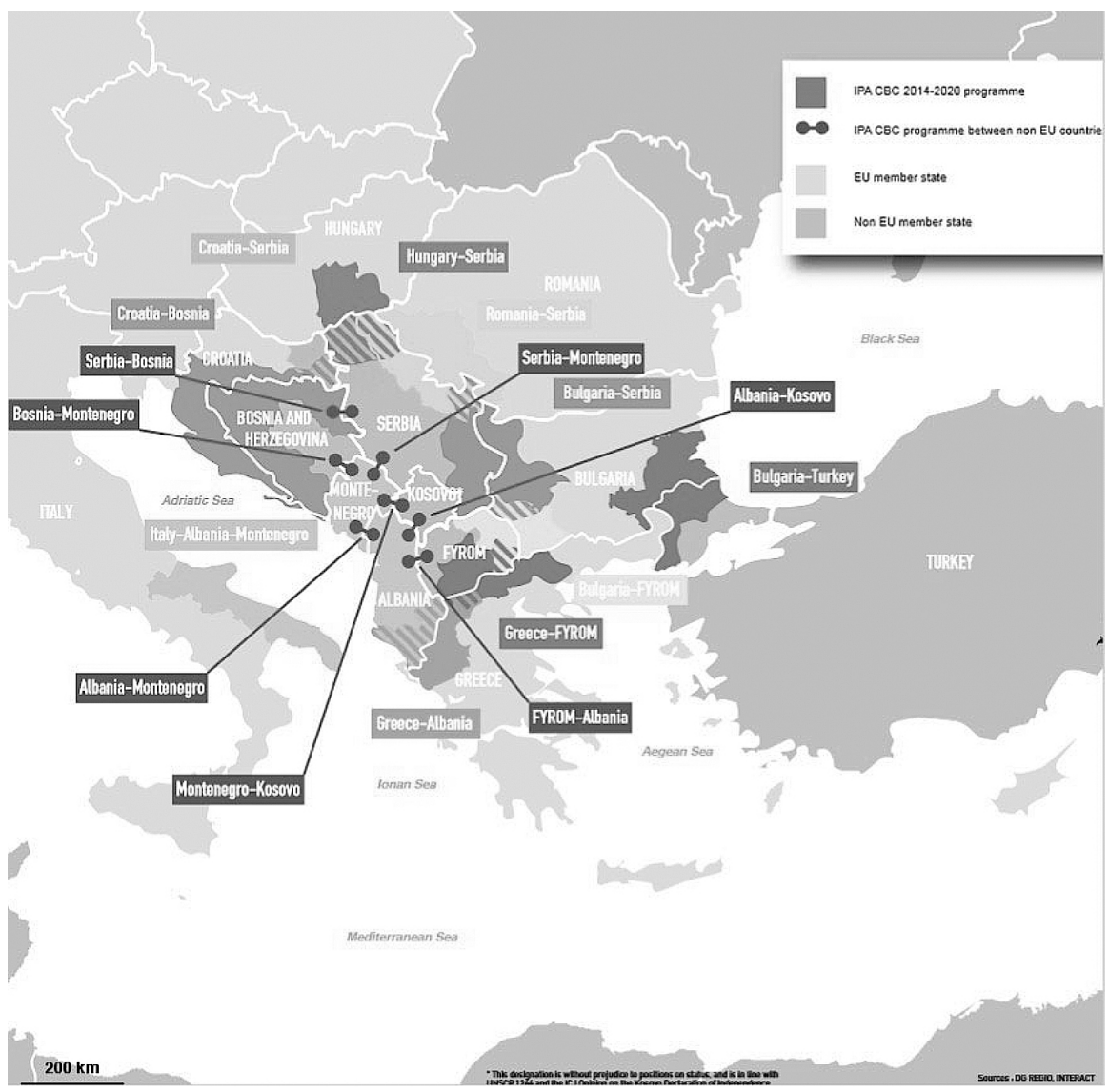

Note: the map was drawn prior to the naming of North Macedonia under the Prespa Agreement. 
Table 1 - Bioregional vs. industrio-scientific paradigm

\begin{tabular}{|l|l|l|}
\hline & Bioregional paradigm & Industrio-scientific paradigm \\
\hline Scale & Region & State \\
\hline & Community & Nation/world \\
\hline Economy & Conservation & Exploitation \\
\hline & Stability & Change/progress \\
\hline & Self-sufficiency & World economy \\
\hline & Cooperation & Competition \\
\hline Polity & Decentralisation & Centralisation \\
\hline & Complementarity & Hierarchy \\
\hline & Diversity & Uniformity \\
\hline Society & Symbiosis & Polarisation \\
\hline & Evolution & Growth/violence \\
\hline & Division & Monoculture \\
\hline
\end{tabular}

Source: Sale (1985), p. 50

This sort of approach allows us to view Bosnia and Herzegovina from a different perspective. We can identify eight different river basins, six of them belonging to the cross-border Sava River basin. Adopting a bioregional approach may eventually lead to the foundation of a cross-border river basin organisation on the model of the International Sava River Basin Organisation established in 2004 whose permanent secretariat, based in Zagreb, started work in 2006.

Furthermore, the devastating floods of May 2014 significantly increased interest in a bioregional approach: first, flood risk maps were established; second, various disaster risk reduction projects were initiated under the umbrella of the European Union and/or various intergovernmental agencies (such as UNICEF, UNESCO and UNDP).

Were we to combine each of the flood hazard map, the fire hazard map, the earthquake hazard map and the GDP exposure to flood risk map, produced by the UN Office for Disaster Risk Reduction (see Map 2, as an example of only one of these), we would see the country of Bosnia and Herzegovina 'naturally' divided into functional regions which simply do not follow the 'logic' of the Dayton Agreement.

We can already see that more and more local stakeholders are becoming active at the regional level in different ways. Among these, a coalition for the protection of rivers (Koalicija za zaštitu rijeka Bosne i Hercegovine) protested in summer 2021 against the construction of a hydroelectric power plant on the River Neretva near Konjic in the southern part of the country. This network, established in 2016, gathers together more than twenty organisations engaged in environmental protection and has adopted a Declaration on the suspension of plans for the construction of hy- 
dropower plants and on the ecological use of rivers. ${ }^{7}$ At the time of writing, the protests appear to have been successful with the cancellation of the construction permits for the Srijanski Most and Gorovnik Usce dam projects.

Another approach is illustrated by Smirna Kulenović's 'Naša porodična bašta' ['Our family garden'] (2021): this participative performance of 100 women coming together to plant 1000 calendula plants - thus medical herbs - in order to heal the now abandoned war trench on the first line of defence front line at Zlatiste hill (Sarajevo) during the 1992-1995 war. Among those present was the grandfather of the artist, who was in this trench during the war. This very first organic monument in the country intends to heal the land as well as its people by taking care of the trauma experienced both by the landscape and the people. It also stands for a creative and pragmatic way of how to 'be with' and how to 'stay with the trouble'.

\section{Map 2 - Bosnia and Herzegovina GDP exposure to flood risk}

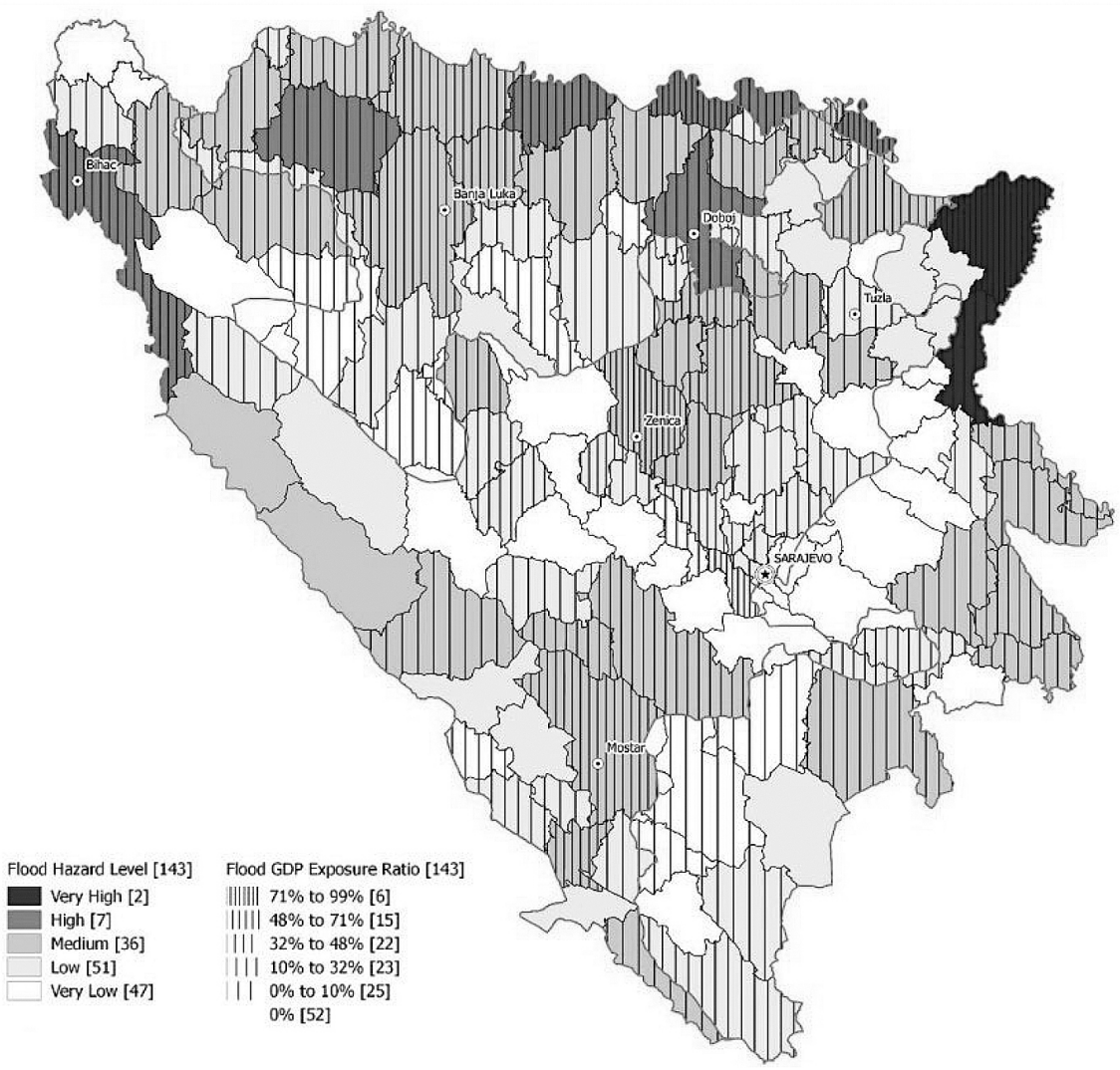

(C) United Nations Office for Disaster Risk Reduction, 2016

7 See http://rijekebih.org/index.php/deklaracija/. 
Further research has to be conducted in order to see to what extent this regional approach is invested in by local stakeholders, whether citizens view it as their 'lifeplace' and how it is linked to the political regions involved in the EU and/or Council of Europe regional programmes. The question remains open, however, as to whether such regions could, eventually, over time, replace the dysfunctional entities established under the framework set out in the Dayton Agreement. Of course, the urban level needs absolutely to be included - and not only the existing urban centres but also the potential of libertarian municipalism (as formulated by the eco-anarchist Murray Bookchin - see Bookchin 1982, 1990a and 1990b) needs to be explored with this in mind.

\section{Conclusions}

I have to insist that the very idea of multi-level and multi-scalar processes, instead of establishing a hierarchy, combines the various 'structures', or actors, involved. What matters therefore is to understand and foster dynamic scale-free and polycentric networks. Network visualisation - encompassing natural, cultural and social phenomena - may capture the underlying structures and relationships, highlight hidden patterns (Stand 2020) and possibly map out a different - multi-floor - country which complements the traditional geopolitical approach. In my view, these dynamic distributive systems are driven by 'structures' characterising the decentralised approach and thus corresponding to the bioregional paradigm briefly presented here.

This also fits with Pierre Rosanvallon's concept of 'democracy's floating meaning', as related to 'democratic indeterminacy' (Rosanvallon 2019: 28; and see the reference below to the work of Claude Lefort), and thus expresses the idea that democracy is an open-ended project. Opposing counter-democracy supposes that we are able to offer an alternative. Among the options proposed by Rosanvallon, as counterbalance to the simplistic temptations of populism, are to complicate and to multiply democracy instead of seeking to simplify it (Rosanvallon 2020: 252). Notably, this also corresponds with Roberto Esposito's viewpoint mentioned above (Esposito 2020: 78).

Furthermore, overcoming the mantra of transitology - made by the techno-politics of democratisation and thus referring to engineered democracy and forced democratisation - requires us to excavate the notion of 'savage democracy' promoted by Claude Lefort. Referring to Machiavelli, Lefort recalls that the very idea of law has to be dissociated from that of moderation:

It no longer necessarily arises from the intervention of a reasonable instance. Rather, the law proves to be connected with the excessive desire for liberty. (Lefort 2000: 144).

The 'life-place' approach corresponds to this quite precisely, extending the rights of citizens, increasing the plurality of voices and expressions to let the people speak and, in consequence: '[multiplies]... the terms of a continuous democracy', making it polyphonic. Populism rests on exactly the opposite.

A vivid and passionate democracy is also, as mentioned above, characterised by its radical indeterminacy. As emphasised by Lefort: 
The modern democratic society seems to me in fact that society in which power, law and knowledge are subjected to the test of radical indeterminacy; society turned into the theater of an adventure that does not allow itself to be subdued, in which the instituted never becomes fully established, in which the known is undermined by the unknown, in which the present reveals itself unnameable, encompassing multiple social times, displaced from each other in simultaneity, or named in the mere fiction of the future; an adventure such that the search for identity does not come off [deficit: detach, undo, untie] from the experience of division. (Lefort 1981: 174)

Democracy is, the same as Europe, 'an unfinished adventure', in the title of Zygmunt Bauman (2004). Instead of 'democratic techno-politics' and disenchantment, 'democracy's indeterminacy' and 'politics of dwelling' are the factors which shape a truly effective and open democracy. This renders transition, therefore, an uncharted journey in the land of democracy.

\section{References}

Ágh, Attila (2019) Declining Democracy in East Central Europe Cheltenham: Edward Elgar.

Bacon, Francis Novum Organum (1620), Aphorism 31, edited by Jonathan Francis Bennett (2017).

Badie, Bertrand (2020) Rethinking International Relations Cheltenham: Edward Elgar.

Bauman, Zygmunt (2004) Europe: An Unfinished Adventure Cambridge: Polity Press.

Peter Berg (1005) Discovering Your Life-Place: A First Bioregional Workbook San Francisco: Planet Drum Foundation.

Bieber, Florian (2020) The Rise of Authoritarianism in the Western Balkans Cham: Palgrave Macmillan.

Bookchin, Murray (1982) The Ecology of Freedom Palo Alto: Cheshire Books.

Bookchin, Murray (1990a) Remaking Society Montréal: Blackrose Books.

Bookchin, Murray (1990b) The Philosophy of Social Ecology Montréal: Blackrose Books.

Bougarel, Xavier (1996) Bosnie, anatomie d'un conflit Paris: La Découverte.

Esposito, Roberto (2011) Immunitas: The Protection and Negation of Life Cambridge: Polity Press.

Esposito, Roberto (2020) 'The Twofold Face of Immunity' Crisis and Critique 7(3): 73-79.

Glotfelty, Cheryll and Eve Quesnel (2015) The Biosphere and the Bioregion. Essential Writings of Peter Berg London: Routledge.

Haraway, Donna (2016) Staying with the Trouble Durham: Duke University Press. 
Lefort, Claude (1981) L'invention de la démocratie Paris: Seuil.

Lefort, Claude (2000) Writing, the Political Test Durham: Duke University Press.

Nancy, Jean-Luc (2021) Doing London: Seagull Books.

Napier, A. David (2003) The Age of Immunology: Conceiving a Future in an Alienating World Chicago: University of Chicago Press.

Neyrat, Frédéric (2018) The Unconstructable Earth. An Ecology of Separation New York: Fordham University Press.

Repe, Božo (2015) Milan Kučan, prvi predsednik ['First President'] Ljubljana: Modrijan.

Rosanvallon, Pierre (2019) 'The Political Theory of Democracy' in Oliver FlügelMartinsen, Franziska Martinsen, Stephen W. Sawyer and Daniel Schulz (Eds) Pierre Rosanvallon's Political Thought. Interdisciplinary Approach Bielefeld: Bielefeld University Press.

Rosanvallon, Pierre (2020) Le siècle du populisme Paris: Seuil.

Sale, Kirkpatrick (1985) Dwellers in the Land: The Bioregional Vision San Francisco: Sierra Club Books.

Scoones, Ian and Andy Stirling (2020) The Politics of Uncertainty. Challenges of Transformation London: Routledge.

Solioz, Christophe (2017) Thinking the Balkans Out of the Box: EU Integration and Regional Cooperation Baden-Baden: Nomos.

Solioz, Christophe (2020a) 'Deconsolidation and de-democratisation: Current western Balkans experience of the transition' SEER Journal for Labour and Social Affairs in Eastern Europe 23(2): 187-207.

Solioz, Christophe (2020b) Viva la Transición. The Balkans from the Post-Wall Era to Post-Crisis Future Baden-Baden: Nomos.

Stand, Alanna (2020) Hidden Patterns. Visualizing Networks at BarabásiLab Berlin: Hatje Cantz.

Stubbs, Paul and Christophe Solioz (2012) Towards Open Regionalism in South East Europe Baden-Baden: Nomos.

Thayer, Robert L., Jr. (2003) LifePlace. Bioregional Thought and Practice Berkeley: University of California Press.

Tilly, Charles (2007) Democracy Cambridge: Cambridge University Press.

'Kučanov "non-paper”: Bivši predsednik pravi, da Janševa vlada preusmerja pozornost' ['Kučan's "non-paper": The former president says the Janša government is diverting attention'] Večer 11 June 2021, accessed 13 October 2021 at: https:// 
www.vecer.com/slovenija/kucanov-non-paper-pahor-se-je-oglasil-da-bi-porociloo-bih-moralo-ostati-zaupno-10245048.

Christophe Solioz is Professor of Philosophy at the Collège de Genève, Rue Théodore De-Bèze 2-4, 1204 GENEVE, Switzerland. e-mail: csolioz@mac.com.

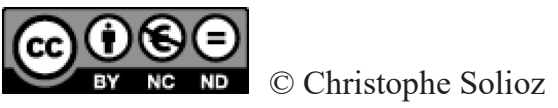

